\title{
Paternity identification in sugarcane polycrosses by using microsatellite markers
}

\author{
M.A. Xavier ${ }^{1}$, L.R. Pinto ${ }^{1}$, T.M. Fávero ${ }^{1}$, D. Perecin $^{2}$, L.A. Carlini-Garcia ${ }^{3}$ \\ and M.G.A. Landell ${ }^{1}$ \\ ${ }^{1}$ Centro Avançado da Pesquisa Tecnológica do Agronegócio de Cana - IAC/APTA, \\ Ribeirão Preto, SP, Brasil \\ ${ }^{2}$ Departamento de Ciências Exatas, \\ Faculdade de Ciências Agrárias e Veterinárias, Universidade Estadual Paulista, \\ Jaboticabal, SP, Brasil \\ ${ }^{3}$ PRDTA Centro Sul/APTA, Piracicaba, SP, Brasil \\ Corresponding author: L.R. Pinto \\ E-mail: lurossini@iac.sp.gov.br
}

Genet. Mol. Res. 13 (1): 2268-2277 (2014)

Received May 27, 2013

Accepted September 20, 2013

Published March 31, 2014

DOI http://dx.doi.org/10.4238/2014.March.31.7

\begin{abstract}
Although polycrosses have been used to test the potential of cross-combination of a large number of sugarcane parents, the male parent of the half-sib progenies produced is unknown. The present study aimed to integrate the molecular marker technology to the sugarcane polycross approach by the application of microsatellite markers to identify the male parent of 41 elite clones derived from polycross families. Ten microsatellite [single sequence repeats (SSRs)] primer pairs were used to identify the most likely male parent considering markers present in the selected clone but absent in the female parent. The number of alleles generated by the 10 microsatellite primer pairs ranged from 102 (cross-pollination lantern 4) to 120 (cross-pollination lantern 2) with an average of 113.25 alleles per SSR. The average genetic similarity among the involved parents in the polycrosses was $45.9 \%$. The results of the analysis of the SSR markers absent in the female parent and present only in the selected clone as well as the genetic
\end{abstract}


similarity values allowed the identification of the most likely male parent in $73 \%$ of the total clones evaluated and also to detect probable contaminations. The obtained results highlight the importance of using molecular marker technology in the identification and confirmation of the male parent of high-performance clones derived from polycrosses in the sugarcane breeding programs.

Key words: Progenies; Sugarcane breeding; Genetic dissimilarity

\section{INTRODUCTION}

The primary strategy in breeding programs of vegetatively propagated crops, such as sugarcane, is to obtain hybrids between elite genotypes, like commercial cultivars or clones whose agricultural potential was confirmed through progeny performances. Genetic variability in breeding programs has been increased by plant breeders by using basically 2 types of crosses: bi-parental and polycrosses (Berding et al., 2004). In non-consolidated active germplasm banks, there is a trend to adopt polycrosses due to the large number of parents involved in this type of cross; these parents are tested for their potential as male or female parents (Berding et al., 2004; Xavier, 2011). In addition, polycrosses are easier to obtain and are costeffective in seed production compared to the bi-parental approach (Berding et al., 2004).

Although the polycross strategy allows the evaluation of several hybrid combinations, the male parent of the derived clone, in principle, is unknown. Thus, one of the major limitations has been attributed to the loss of pedigree information of the obtained progenies (Tew and Pan, 2010), which are generally assumed to be half-sibs of which only the female parent is known. However, molecular profiles generated by molecular markers allow the identification of the male parent of a clone, facilitating pedigree reconstruction of the target progeny (Sefc et al., 1998; Gomez et al., 2008).

In sugarcane breeding programs, molecular markers have many applications such as fingerprinting the hybrid nature of progenies derived from introgression programs, cultivar protection, and identifying the male parent of a clone derived from polycrosses. In all these applications, the most commonly used molecular markers are microsatellite markers (Pan, 2010).

Microsatellites or simple sequence repeats (SSRs) are sequences composed of 1-6 nucleotides (motive) repeated in tandem along the genome. The sequences flanking the SSRs are highly conserved allowing the designing of specific primer pairs for their amplification by polymerase chain reaction (PCR; Jarne and Lagoda, 1996; Selkoe and Toonen, 2006). The advantage of this type of marker is its high degree of polymorphism and reproducibility. Moreover, SSRs are considered highly discriminating bi-parentally inherited co-dominant markers that can be applied widely in paternity and kinship analyses (Chambers and MacAvoy, 2000).

In sugarcane, McIntyre and Jackson (2001) applied molecular markers such as random amplified polymorphic DNA in 8 bi-parental crosses to identify sugarcane progeny derived from selfing. Tew and Pan (2010) used microsatellite markers to identify sugarcane selfing progenies derived from polycrosses.

In the present study, the molecular marker technology was applied as a complementary tool in the sugarcane polycross approach to identify the most likely male parent of 41 elite clones derived from polycross families. 


\section{MATERIAL AND METHODS}

The polycrosses were performed in 2007 at the "Empresa Baiana para o Desenvolvimento da Agricultura" experimental station. The polycrosses were performed under cross-pollination lanterns, and the list of male and female parents and clones (progenies) derived from each cross-pollination lantern are presented in Table 1. The clones derived from polycross families were selected according to the family merit point, a value obtained as a function of the family mean plus the standard deviation of each polycross family for important agronomic traits such as Pol\% Cane, Brix, and TSH, over tones of sugarcane per hectare (Xavier, 2011; Xavier et al., 2012).

\section{DNA extraction}

Total genomic DNA was obtained from $300 \mathrm{mg}$ meristematic tissue (leaf roll) using the extraction procedure described by Aljanabi et al. (1999). The extracted DNA was quantified in the presence of $\lambda$ phage DNA on $0.8 \%(\mathrm{w} / \mathrm{v})$ agarose gel stained with ethidium bromide.

\section{Microsatellite assays}

PCR analysis was conducted in a final reaction volume of $15 \mu \mathrm{L}$ (40 ng DNA template, $100 \mu \mathrm{M}$ of each dNTP, $2.0 \mathrm{mM} \mathrm{MgCl}, 10 \mathrm{mM}$ Tris-HCl, $50 \mathrm{mM} \mathrm{KCl}, 0.2 \mu \mathrm{M}$ of each primer pair, and $0.5 \mathrm{U}$ Taq DNA polymerase). The amplification conditions were performed according to Pinto et al. (2006). Ten primer pairs, i.e., SMC1047HA, SMC2017FL, SMC31CUQ (Pan, 2006), CV38 (Maccheroni et al., 2007), SCA48, SCB82, SCB312, SCB381, SCB436 (Oliveira et al., 2009), and SCC01 (Pinto et al., 2004), were used for genotyping. The amplification products were resolved on $6 \%$ denaturing polyacrylamide gels and silver stained (Creste et al., 2001).

\section{Data analysis}

The female, clones, and male parents involved in their respective polycrosses were genotyped on the basis of the presence (1) and absence (0) of markers (alleles). The markers present in the clone but absent in their female parent were considered to identify the most likely male parent in each cross, according to Buteler et al. (1997). The molecular data were used to construct a genetic similarity matrix adopting the Jaccard coefficient: $G S_{\mathrm{ij}}=\mathrm{a} /(\mathrm{a}+\mathrm{b}+\mathrm{c})$, where $G S_{\mathrm{ij}}$ is the measure of the genetic similarity (GS) between individuals $i$ and $j, a$ is the number of polymorphic markers present in both individuals, $b$ is the number of bands present in $i$ and absent in $j$, and $c$ is the number of bands present in $j$ and absent in $i$ (Jaccard, 1908); the data were analyzed using the NTSYS-pc statistical package, version 2.1 (Rohlf, 1993). This software was also used to build a dendrogram on the basis of the unweighted pair group method with arithmetic mean (UPGMA) (Sneath and Sokal, 1973) to visualize the genetic similarity relationship among all the genotypes (male and female parents and clones) within each crosspollination lantern. The coefficient of variation $(\mathrm{CV} \%)$ was calculated in relation to the number of markers (alleles) by using the bootstrap method with 10,000 replicates to measure the accuracy of the GS estimates within each cross-pollination lantern by using the dBood software (Coelho, 2001). 
Table 1. Clones (progenies) with respective female parents and most likely male parent identified by molecular markers with the respective genetic similarity coefficient between the clone (progeny) and their parents given in percentage, and also the parents present in their cross-pollination lanterns.

\begin{tabular}{|c|c|c|c|c|}
\hline \multirow{2}{*}{$\begin{array}{l}\text { Clones } \\
\text { (progenies) }\end{array}$} & \multicolumn{2}{|c|}{ Identified parents } & \multicolumn{2}{|c|}{ Parents in the lantern } \\
\hline & Female parent (q) & Most likely male parent & (q) Female & (১) Male \\
\hline \multicolumn{5}{|l|}{ Cross-pollination lantern 1} \\
\hline $\mathrm{I} 31$ & IACSP97-6680 $(55.00 \%)$ & IACSP97-2084 (56.09\%) & IACSP96-2037 & IACSP94-2111 \\
\hline $\mathrm{I} 32$ & IACSP97-6680 (48.50\%) & SP81-1763 (68.30\%) & IACSP98-6202 & IACSP97-6682 \\
\hline $\mathrm{I} 24$ & IACSP98-2053 (62.10\%) & NI & IACSP95-2216 & IACSP97-2084 \\
\hline $\mathrm{I} 25$ & IACSP98-2053 (56.30\%) & SP81-1763 (68.30\%) & IACSP98-3022 & IACSP98-3067 \\
\hline \multirow[t]{7}{*}{$\mathrm{I} 28$} & IACSP98-2053 (54.10\%) & IACSP97-2084 (69.80\%) & IACSP97-6680 & IAC91-3111 \\
\hline & & & IACSP98-5046 & SP80-3280 \\
\hline & & & IACSP98-3056 & SP83-2847 \\
\hline & & & IACSP98-3099 & \\
\hline & & & SP80-1842 & \\
\hline & & & SP81-1763 & \\
\hline & & & IACSP98-2053 & \\
\hline \multicolumn{5}{|l|}{ Cross-pollination lantern 2} \\
\hline $\mathrm{I} 20$ & IACSP98-3028 (66.10\%) & NI & IACSP98-3028 & SP84-7017 \\
\hline I39 & IACSP98-3028 (60.90\%) & IACSP94-2111 (58.20\%) & IACSP96-3200 & IACSP95-3028 \\
\hline \multirow[t]{11}{*}{$\mathrm{I} 27$} & IACSP98-6209 (65.40\%) & SP84-7017 (51.70\%) & IACSP97-7077 & IACSP94-2111 \\
\hline & & & IACSP96-1107 & IACSP94-2094 \\
\hline & & & IACSP99-3009 & IACSP97-3313 \\
\hline & & & IACSP99-3332 & IACSP97-6671 \\
\hline & & & IACSP99-3390 & IACSP99-3012 \\
\hline & & & CT97-3060 & CTC1 \\
\hline & & & SP89-1115 & IACSP96-2036 \\
\hline & & & IACSP96-3055 & \\
\hline & & & IACSP96-2008 & \\
\hline & & & IACSP98-6209 & \\
\hline & & & RB92-5345 & \\
\hline \multicolumn{5}{|l|}{ Cross-pollination lantern 3} \\
\hline I12 & NI & NI & NI & IACSP94-2094 \\
\hline I13 & NI & NI & IACSP94-1104 & IACSP95-5011 \\
\hline I58 & NI & NI & IACSP95-3264 & IACSP97-3354 \\
\hline I41 & NI & NI & IACSP98-3108 & SP80-3280 \\
\hline $\mathrm{I} 47$ & IACSP94-1104 (73.30\%) & RB855453 (55.70\%) & IACSP96-3161 & SP83-2847 \\
\hline I14 & IACSP96-3161 (62.10\%) & IACSP97-6628 (54.00\%) & IACSP96-2067 & SP84-7017 \\
\hline $\mathrm{I} 42$ & IACSP96-3161 (62.50\%) & IACSP97-6619 (71.40\%) & IACSP96-3076 & SP80-185 \\
\hline $\mathrm{I} 21$ & IACSP96-2067 (66.10\%) & IACSP97-3354 (63.50\%) & IACSP97-3311 & RB925211 \\
\hline I 22 & IACSP96-2067 (59.40\%) & IACSP94-2094 (70.20\%) & IACSP97-6619 & RB855453 \\
\hline I48 & IACSP96-2067 (64.50\%) & NI & IACSP97-6628 & SP79-1011 \\
\hline $\mathrm{I} 33$ & IACSP97-3311 (65.50\%) & IACSP96-3076 (54.20\%) & IACSP98-3051 & \\
\hline I38 & IACSP97-6619 (58.70\%) & NI & IACSP97-7077 & \\
\hline I15 & IACSP98-3051 (64.10\%) & RB855453 (60.70\%) & IACSP98-3068 & \\
\hline I16 & IACSP98-3051 (68.50\%) & IACSP97-3354 (57.60\%) & IACSP98-3067 & \\
\hline I51 & IACSP98-3051 (65.10\%) & SP80-185 $(46.60 \%)$ & & \\
\hline $\mathrm{I} 23$ & IACSP98-3068 (57.60\%) & NI & & \\
\hline I46 & IACSP98-3068 (43.10\%) & IACSP97-3311 (70.70\%) & & \\
\hline I66 & IACSP98-3068 (47.10\%) & IACSP97-6628 (60.00\%) & & \\
\hline I67 & IACSP98-3068 (48.50\%) & IACSP97-6628 (59.00\%) & & \\
\hline I29 & IACSP98-3067 (65.50\%) & SP79-1011 (41.80\%) & & \\
\hline \multicolumn{5}{|l|}{ Cross-pollination lantern 4} \\
\hline $\mathrm{I} 37$ & IACSP97-2237 (59.30\%) & IACSP95-5094 (69.50\%) & IACSP96-2019 & IACSP95-2288 \\
\hline I49 & IACSP97-2237 (77.10\%) & IACSP95-3264 (69.20\%) & IACSP97-2237 & SP80-185 \\
\hline $\mathrm{I} 40$ & IACSP99-3015 (55.90\%) & IACSP95-5094 (53.70\%) & IACSP95-5037 & SP87-365 \\
\hline I68 & IACSP99-3015 (54.10\%) & NI & IACSP95-5094 & IAC91-3111 \\
\hline I04 & IACSP99-3032 (66.10\%) & IAC91-3111 (56.70\%) & IACSP98-3050 & IACSP95-3264 \\
\hline I69 & IACSP99-3032 (62.10\%) & IACSP95-3264 (64.20\%) & IACSP99-3011 & IACSP95-5094 \\
\hline I17 & IACSP99-3049 (36.20\%) & NI & IACSP99-3015 & IACSP97-6682 \\
\hline $\mathrm{I} 18$ & IACSP99-3049 (68.30\%) & IACSP95-5037 (57.10\%) & IACSP99-3032 & SP91-3011 \\
\hline I19 & IACSP99-3049 (71.20\%) & SP79-1011 (58.10\%) & IACSP99-3049 & SP79-1011 \\
\hline $\mathrm{I} 34$ & IACSP99-3049 (71.70\%) & IACSP99-3011 (51.60\%) & IACSP99-3090 & RB925111 \\
\hline $\mathrm{I} 35$ & IACSP99-3049 (55.60\%) & IACSP95-5037 (60.00\%) & IACSP99-3357 & \\
\hline $\mathrm{I} 36$ & IACSP99-3049 (58.20\%) & IACSP95-5037 (57.60\%) & SP91-1049 & \\
\hline
\end{tabular}

Female $(+\circ)$ and male $\left({ }^{\curvearrowright}\right)$ parents. $\mathrm{NI}=$ non-identified male parent. In parentheses the genetic similarity coefficient between the clone (progeny) and their parents, given in percentage. 


\section{RESULTS}

\section{Microsatellite polymorphism}

The 10 microsatellite primers pairs (SSRs) used to identify the most likely male parent produced many alleles ranging from 102 (cross-pollination lantern 4) to 120 (crosspollination lantern 2) with an average of 113.25 alleles per lantern. The minimum genetic similarity among the parents used in each cross-pollination lantern ranged from $29.4 \%$ between cultivars IACSP98-3056 and IACSP98-5046 (cross-pollination lantern 1) to $34.3 \%$ between IACSP99-3015 and IACSP95-5094 (cross-pollination lantern 4), while the maximum genetic similarity ranged from $66.7 \%$ between cultivars IACSP96-2008 and IACSP96-3200 (cross-pollination lantern 2) to $73.7 \%$ between the cultivars RB855453 and IACSP97-6628 (cross-pollination lantern 3; Table 2). Overall, the average genetic similarity among all the parents involved in the polycrosses was $45.9 \%$. The mean $\mathrm{CV} \%$ value ranged from $13.07 \%$ (cross-pollination lantern 3) to $13.90 \%$ (cross-pollination lantern 1) achieved with 102 and 119 markers, respectively (Table 2).

\begin{tabular}{|c|c|c|c|c|c|}
\hline Cross-pollination lantern & NA & GSmin $(\%)$ & GSmax $(\%)$ & GSm & $\mathrm{CV} \%$ \\
\hline 1 & 119 & $\begin{array}{c}29.4 \\
\text { (IACSP98-3056 vs IACSP98-5046) }\end{array}$ & $\begin{array}{c}69.8 \\
\text { (SP80-3280 vs IACSP94-2111) }\end{array}$ & 44.0 & 13.90 \\
\hline 2 & 120 & $\begin{array}{c}31.5 \\
\text { (CT973060 vs IACSP99-3009) }\end{array}$ & $\begin{array}{c}66.7 \\
\text { (IACSP96-2008 vs IACSP96-3200) }\end{array}$ & 45.6 & 13.59 \\
\hline 3 & 112 & $\begin{array}{c}33.8 \\
\text { (RB925211 vs IACSP96-3161) }\end{array}$ & $\begin{array}{c}73.7 \\
\text { (RB855453 vs IACSP97-6628) }\end{array}$ & 47.1 & 13.07 \\
\hline 4 & 102 & $\begin{array}{c}34.3 \\
\text { (IACSP99-3015 vs IACSP95-5094) }\end{array}$ & $\begin{array}{c}67.2 \\
\text { (SP79-1011 vs IACSP99-3032) }\end{array}$ & 46.9 & 13.61 \\
\hline $\begin{array}{l}\text { Total } \\
\text { Average }\end{array}$ & $\begin{array}{l}453 \\
113.25\end{array}$ & & & 45.9 & \\
\hline
\end{tabular}

\section{Progeny identification with SSRs}

The male parent could be identified for $73 \%$ of the total selected clones (Table 1), indicating that the adopted strategy of considering, for each cross-pollination lantern, the alleles present in the male parents and clones but absent in the mothers, in addition to the genetic similarity information among the genotypes (parents and clones) was an efficient way to identify the most likely male parents of each clone.

\section{Cross-pollination lantern 1}

For clones I30, I31, I32, I25, and I28, the most likely male parents were cultivars SP81-1763, IACSP97-2084, SP81-1763, SP81-1763, and IACSP97-2084, respectively. These male parents had all the markers that were present in the clone, but absent in their female parent, indicating the male parent from which the marker was inherited. For clone I24, none of the parents present in the cross-pollination lantern had all the markers present in the clone 
and absent in their respective female parent IACSP98-2053. The highest genetic similarity observed between clone I24 and all the other parents present in the cross-pollination lantern corresponded to its female parent IACSP98-2053 (62.1\%), which probably confirms that this clone is actually derived from this cultivar (Table 1; Figure 1).

\section{Cross-pollination lantern 2}

The cultivars SP84-7017 and IACSP94-2111 were identified as the most likely male parents of the clones I27 and I39, respectively (Table 1). None of the parents of the crosspollination lantern 2 had all the markers present in clone I20 and absent in their respective female parent (IACSP98-3028). The clones I20 and I39 are half-sibs (Table 1) and showed $45.6 \%$ of genetic similarity between them. The dendrogram (Figure 1) showed that clones I20 and I39 were clustered in the same group as their female parent IACSP98-3028, and I20 is more similar to the female genitor than I39.

\section{Cross-pollination lantern 3}

The most likely male parents for clones I15, I21, I22, I29, I33, I46, and I51 were cultivars RB855453, IACSP97-3354, IACSP94-2094, SP79-1011, IACSP96-3076, IACSP97-3311, and SP80-185, respectively. These clones were found close to their respective female parents in the dendrogram, except in the case of clones I22 and I46, and their respective IACSP94-2094 and IACSP98-3068 mothers, that were not close (Figure 2). Due to the tie between parents sharing the same number of markers absent in the female parent and present only in the target clone, the highest value of genetic similarity observed between the clone and the male parent was used as tie-breaker. This criterion suggested that the most likely male parents of clones I47 and I14 are cultivars RB855453 and IACSP97-6628, respectively. The similarity between I47 and RB855453 was 56\%, and that between I14 and IACSP97-6628 was 54\%. For clones I16, I42, I66, and I67, the most likely male parents were IACSP97-3354, IACSP97-6619, IACSP97-6628, and IACSP97-6628, respectively. On the other hand, the male parent for the clones I12, I13, I58, I41, I48, I38, and I23 were not identified either through the exclusion analysis or genetic similarity.

\section{Cross-pollination lantern 4}

The cultivar IACSP95-5094 was identified as the most likely parent for clones I37 and I40, and IACSP95-5037 was the most likely parent for clones I18, I35, and I36. For clones I04, I69, I19, and I34, IAC91-3111, IACSP95-3264, SP79-1011, and IACSP99-3011 were identified as the most likely male parents, respectively (Table 2).

Exclusion analysis allowed the selection of 2 cultivars as the potential male parents for clone I49, since the markers present in clone I49 and absent in the female parent were found in both candidate male parents (IACSP99-3090 and IACSP95-3264). In this case, the cultivar with the highest genetic similarity with clone I49 was considered as the male parent, i.e., IACSP95-3264 (0.692; Figure 2). The male parent of the clones I17 and I68 was not identified. 


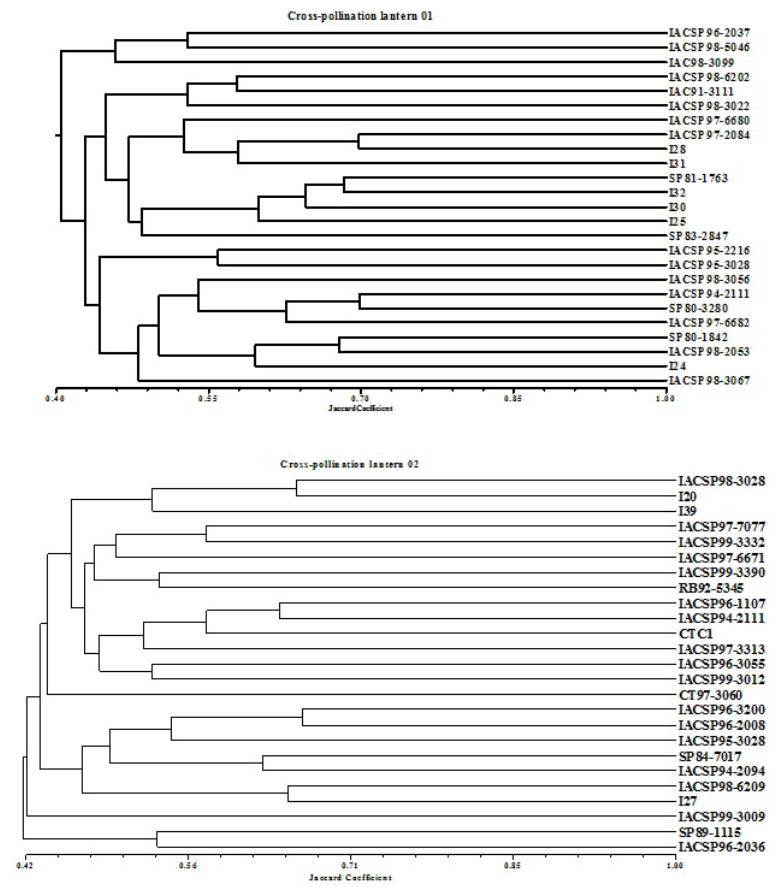

Figure 1. UPGMA dendrogram based on genetic similarity matrix (Jaccard coefficient) among parents and clones from the cross-pollination lanterns 1 (above) and 2 (below).
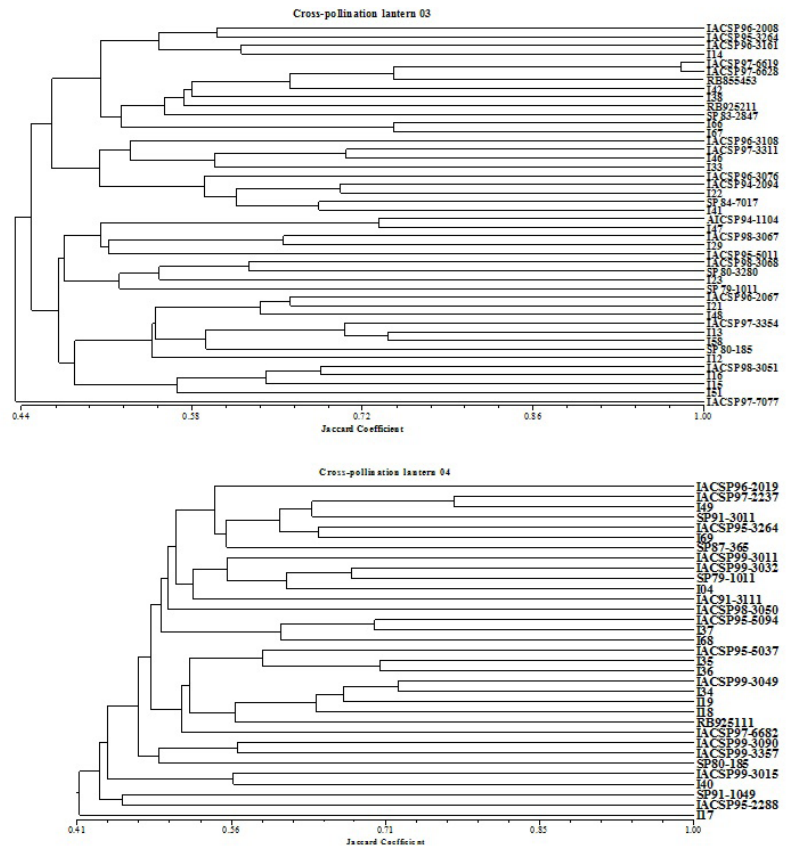

Figure 2. UPGMA dendrogram based on genetic similarity matrix (Jaccard coefficient) among parents and clones from the cross-pollination lanterns 3 (above) and 4 (below). 


\section{DISCUSSION}

In the present study, the strategy applied to identify the male parent, in which only the markers present in the clone (progeny) and absent in the mother were considered (Buteler et al., 1997), was efficient to identify the male parent of polycross-derived clones of sugarcane, a crop species with a high genetic complexity and ploidy level. In fact, $73 \%$ of the clones had their male parent identified by molecular markers generated from 10 microsatellite primer pairs. These 10 SSRs produced reliable measures of the genetic similarity in each cross-pollination lantern since the CV\% was around $13 \%$ close to the recommended value of $10 \%$ (Lima et al., 2002). Moreover, the identified clones were derived from cross-pollination lanterns involving a considerable number of female and male parents, ranging from 19 (crosspollination lantern 1) to 23 (cross-pollination lantern 3 ), with an average genetic similarity among the male parents (pollen donors) ranging from $46.2 \%$ (cross-pollination lantern 1) to 58\% (cross-pollination lantern 3). Tew and Pan (2010) also used microsatellite markers to identify the male parent of polycross-derived clones involving a much smaller number of parents ( 7 parents in just one cross-pollination lantern) and were able to identify the male parent of $79-99 \%$ of the evaluated clones.

In this study, the clones were selected on the basis of the concept of family merit point, suggesting that these clones had high concentration of favorable alleles. The identification of the most likely male parent significantly contributes to the breeding program since it might signal potential favorable combinations that can be exploited in the form of bi-parental crosses. In this sense, the use of molecular marker technology to identify the male parent can be directed only to the clones of interest, reducing the costs of molecular analysis and increasing its impact on the breeding program, and possibly reducing the time for obtaining new cultivars.

The identification of the male parent of an elite clone also rules out the possibility of selfing. It is interesting to note that, among the clones (progenies) evaluated, none was derived from self-fertilization, which can probably be attributed to the fact, as mentioned earlier, that they were previously selected for attributes such as productivity (TSH). This trait is greatly affected by inbreeding depression (Silva and Gonçalves, 2011). According to McIntery and Jackson (2001), in breeding programs, there is a trend to evaluate and select the most vigorous clones in order to produce cultivars with higher productivity, since reduction in vigor has been used as the main criterion for the identification and discarding of selfing progenies. Further, since sugarcane is an outbreeding species, the self-breeding ratio is very low, which might be one of the reasons for the low number of self-fertilization crosses.

Each year, during the hybridization season, hundreds of crosses are performed by sugarcane breeding programs yielding thousands of seeds or seedlings to be evaluated in the selection phases. During this process, which involves the preparation of arrows (inflorescence) for crossing, seed processing, progeny planting at the field, might lead to exchange of progenies, mixing, and pollen or seed contamination. According to Pan (2010), the probability of error in the identification is considerably higher in clones or cultivars used as parents, which are propagated during several times over the years.

Some clones that could not have their male parents identified, probably might have originated from pollen that came from outside the cross-pollination lantern carried by bees, commonly observed in sugarcane hybridization stations. However, in the case of clones I12, I13, I41, and I58, all from the same mother, identifying the male parent was not possible, 
thereby suggesting that the female parent was misidentified during the lantern assembly. In fact, the leaf roll used for molecular analyzes was not collected directly from the female parents in the cross-pollination lanterns, at the time of crossing, but was obtained from the sugarcane collections maintained at the experimental station in Ribeirão Preto, SP. These observations emphasize the importance of using molecular marker technology applied to validate the identity of parents involved in the polycross during the hybridization phase and to identify the male parent of elite clones derived from polycrosses.

\section{ACKNOWLEDMENTS}

Research supported by Fundação de Amparo à Pesquisa do Estado de São Paulo (FAPESP, Bioen \#2008/56146-5) and IAC (Instituto Agronômico de Campinas).

\section{REFERENCES}

Aljanabi SM, Forget L and Dookun A (1999). An improved and rapid protocol for the isolation of polysaccharide- and polyphenol-free sugarcane DNA. Plant Mol. Biol. Rep. 17: 281.

Berding N, Hogarth M and Cox M (2004). Sugarcane. In: Plant Improvement of Sugarcane (James G, ed.). Blackwell Science, Oxford, 2-53.

Buteler MJ, LaBonte DR and Macchiavelli RE (1997). Determinig paternity in polyploids: hexaploid simulation studies. Euphytica 96: 353-361.

Chambers GK and MacAvoy ES (2000). Microsatellites: consensus and controversy. Comp. Biochem. Physiol. B Biochem. Mol. Biol. 126: 455-476.

Coelho ASG (2001). Dboot - Avaliação dos Erros Associados a Estimativas de Distâncias/Similaridades Genéticas Através do Procedimento de Bootstrap com Número Variável de Marcadores. Laboratório de Genética Vegetal, Instituto de Ciências Biológicas, UFG, Goiânia.

Creste S, Tulmann NA and Figueira A (2001). Detection of single sequence repeat polymorphisms in denaturing polyacrylamide sequencing gels by silver staining. Plant Mol. Biol. Rep. 19: 299-306.

Gomez SM, Denwar NN, Ramasubramanian T, Simpson CE, et al. (2008). Identification of peanut hybrids using microsatellite markers and horizontal polyacrylamide gel electrophoresis. Peanut Sci. 35: 123-129.

Jaccard P (1908). Nouvelles recherches sur la distribution florale. Bull. Soc. Vaudoise Sci. Nat. 44: 223-270.

Jarne P and Lagoda PJL (1996). Microsatellites: from molecules to populations and back. Tree 11: 424-429.

Lima ML, Garcia AA, Oliveira KM, Matsuoka S, et al. (2002). Analysis of genetic similarity detected by AFLP and coefficient of parentage among genotypes of sugar cane (Saccharum spp.). Theor. Appl. Genet. 104: 30-38.

Maccheroni W, Jordão H, Degaspari R and Matsuoka S (2007). Development of a Dependable Microsatellite-Based Fingerprinting System for Sugarcane. In: Proceedings of the International Society of Sugar Cane Technologistics, Durban.

McIntyre CL and Jackson PA (2001). Low level of selfing found in a sample of crosses in Australian sugarcane breeding programs. Euphytica 117: 245-249.

Oliveira KM, Pinto LR, Marconi TG, Mollinari M, et al. (2009). Characterization of new polymorphic functional markers for sugarcane. Genome 52: 191-209.

Pan YB (2006). Highly polymorphic microsatellite DNA markers for sugarcane germplasm evaluation and variety identity testing. Sugar Technol. 8: 246-256.

Pan YB (2010). Databasing molecular identities of sugarcane (Saccharum spp.) clones constructed with microsatellite (SSR) DNA markers. Am. J. Plant Sci. 1: 87-94.

Pinto LR, Oliveira KM, Ulian EC, Garcia AA, et al. (2004). Survey in the sugarcane expressed sequence tag database (SUCEST) for simple sequence repeats. Genome 47: 795-804.

Pinto LR, Oliveira KM, Marconi T, Garcia AAF, et al. (2006). Characterization of novel sugarcane expressed sequence tag microsatellites and their comparison with genomic SSRs. Plant Breed. 125: 378-384.

Rohlf FJ (1993). NTSYS-pc Numerical Taxonomy and Multivariate Analysis System. Version 1.80. Applied Biostatistics, Setauket.

Sefc KM, Steinkellner H, Glössl J, Kampfer S, et al. (1998). Reconstruction of a grapevine pedigree by microsatellite analysis. Theor. Appl. Genet. 97: 227-231. 
Selkoe KA and Toonen RJ (2006). Microsatellites for ecologists: a practical guide to using and evaluating microsatellite markers. Ecol. Lett. 9: 615-629.

Silva MA and Gonçalves PS (2011). Inbreeding in sugarcane varieties. Ciênc. Rural 41: 580-586.

Sneath PH and Sokal RR (1973). Numerical Taxonomy: The Principles and Practice of Numerical Classification. W.H. Freeman and Company, San Franscico.

Tew TL and Pan Y (2010). Microsatellite (simple sequence repeat) marker-based paternity analysis of a seven-parent sugarcane polycross. Crop Sci. 50: 1401-1408.

Xavier MA (2011). Ponto de Mérito de Família, Parâmetros Genéticos e Identificação de Genitores Masculinos em Policruzamentos de Cana-de-Açúcar. Doctoral thesis, UNESP, Jaboticabal.

Xavier MA, Perecin D, Arantes FC, Pinto LR, et al. (2012). Genetic Parameters Estimates of Families and Progenies. Plant \& Animal Genome Conference, XX. Final Program, Abstract \& Exhibition Guide of the Plant \& Animal Genome Conference, XX, San Diego. 